\title{
Comparative Study for Cervical Spinal Fusion Using Cervical Cages With and Without Bone Granules
}

\author{
MOHAMED MOHAMED, M.D.* and AHMED S. KAMEL ABD EL-WAHAB, M.D.** \\ The Department of Neurosurgery, Faculties of Medicine, Beni Sueif* and Cairo** Universities
}

\begin{abstract}
Background: Cervical spinal fusion is a surgical procedure that joins selected bones in the cervical spine.

The anterior approach to the cervical spine was developed for treatment of cervical disc, it involves removing the symptomatic disc from an anterior approach without placement of a bone graft. Early studies demonstrated fusion rates with Anterior Cervical Discectomy (ACD) were similar to those of procedures of Anterior Cervical Discectomy and Fusion (ACDF) using bone graft.
\end{abstract}

The Anterior Cervical Discectomy and Fusion with Instrumentation (ACDFI) technique involves the additional stabilization of the cervical spine \& graft with instrumentation.

Cages were introduced to be used with either autologous or synthetic bone grafts, promoting stability and encouraging fusion. Comparing to graft alternatives, cage interbody implants have better biomechanical properties, designed to maximise biocompatibility and reduced graft dislodgements, increased fusion rates, and decreased foraminal stenosis. However, placement of implants introduces hardware-related complications.

Aim of the Study: This prospective study aims to compare the results of ACDFI using cages with \& without synthetic bone granules evaluating the outcomes, fusion and associated morbidities.

Patient and Methods: Prospective study of 42 patients operated upon between 2012 and 2014 in Cairo University Hospitals \& Beni Sueif University Hospital with ACDFI using cervical cages. Patients were divided into two groups:

- Group (A) 22 patients operated by ACDFI with placement of cages only.

- Group (B) 20 patient s operated by ACDFI with placement of cages and synthetic bone granules.

Both groups underwent post-operative clinical follow-up for an average of 12 months, and result were evaluated according to radiographic evidence of fusion and Fisher exact probability test was used to compare of fusion of both groups. We made considerations for patient's age, sex, osteoporosis, and smoking habits. We recorded fusion rates, cervical align-

Correspondence to: Dr. Mohamed Mohamed, The Department of Neurosurgery, Faculty of Medicine, Beni Sueif University ment, post-operative complications \& patient satisfaction using Visual Analogue Score (VAS).

Results: 42 patients were included in the study. The mean age was 46,18 of them were female and 24 were male. 29 patient had single level discs and 13 patients had two levels.

One year follow-up fusion rates that were achieved in Group (A) were $81.8 \%$ while Group (B) reached $95 \%$. One year follow-up on achievement of alignment of cervical spine was $90.9 \%$ of patient's in Group (A) and in Group (B) was $95 \%$ of cases.

There were no problems regarding surgical technique or dislodgment in both techniques. Only in one patient in Group (A) CSF leak developed and resolved. One patient in Group (B) developed a keloid at incision site.

Conclusion: Fusion rate is one of several factors that guide surgical decision making for cases requiring ACDFI. Fusion rate is significantly higher in Group (B) using cages filled with synthetic bone granules than in Group (A) with cages only. Age, sex, osteoporosis and smoking status have not given significantly different results between both groups studied.

Key Words: Cervical cages - Discectomy-Bone granule.

\section{Introduction}

CERVICAL spinal fusion is a surgical procedure that joins selected bones in the cervical spine.

Surgical pathologies of the cervical spine have commonly been addressed through anterior and posterior approaches. The anterior approach to the cervical spine was developed in the 1950 s as a treatment for cervical disc. This procedure involved removing the symptomatic disc from an anterior approach without placement of a bone graft. Early studies demonstrated fusion rates with Anterior Cervical Discectomy (ACD) were similar to those of procedures of anterior cervical discectomy and fusion (ACDF) using bone graft $[\mathbf{1 , 2 , 1 5 ]}$.

This extra step has been proposed to promote bony fusion maximizing stability and maintaining 
disc space height reducing risk of foraminal stenosis. Placement of a bone graft also introduced new morbidities of graft dislodgement causing anterior or posterior compression, as well as donorsite complications when autograft is used $[\mathbf{3 , 5 , 1 4}]$

The Anterior Cervical Discectomy and Fusion with Instrumentation (ACDFI) technique involves the additional stabilization of the cervical spine \& graft with instrumentation. Instrumentations includes a wide array of wiring, plates, cages and screws $[4,6,13]$.

Although autologous bone graft remains the gold standard, associated morbidity has promoted alternatives, including allograft, synthetic and factor/cell-based grafts. Cages were introduced to be used with either autologous or synthetic bone grafts, promoting stability and encouraging fusion. Comparing to graft alternatives, cage interbody implants have better biomechanical properties, designed to maximise biocompatibility and reduced graft dislodgements, increased fusion rates, and decreased foraminal stenosis. However, the extra step of implant placement introduces hardwarerelated complications including dislogement, malunion and infection [7-9,16].

\section{Objective:}

This prospective study aims to compare the results of ACDFI using cages with \& without synthetic bone granules evaluating the outcomes, fusion and associated morbidities in an attempt to evaluate the omission of the bone grafting step from the technique [10-12]

\section{Material and Methods}

Prospective study of 42 patients operated upon between 2012 and 2014 in Cairo University Hospitals \& Beni Sueif University Hospital with ACDFI using cervical cages.

\section{Patients were divided into two groups:}

- Group (A) 22 patients operated by ACDFI with placement of cages only.

- Group (B) 20 patient s operated by ACDFI with placement of cages and synthetic bone granules.

Both groups underwent post-operative clinical follow-up for an average of 12 months, result were evaluated according to radiographic evidence of fusion and Fisher exact probability test was used to compare of fusion in both groups, making considerations for patient's age, sex, osteoporosis, and smoking habits. We recorded fusion rates, cervical alignment, post-operative complications and patient satisfaction using Visual Analogue Score (VAS).

The study was arbitrarily limited to a comparison of the two techniques in patients with cervical disc disease at one or two levels between C-3 and C-7.

\section{Exclusion criteria:}

1- Three level discs or more.

2- Neck pain only without radiculopathy.

3- Cervical spine anomalies.

Patients were subjected to:

- History taking.

- General and neurological examination focusing on motor and sensory examination.

- Investigations: Pre-operative MRI cervical spine (T1 and T2 images, axial and sagittal views), plain X-ray cervical spine ( A.P. view, lateral view in neutral position and lateral views in full flexion and extension) $\pm \mathrm{CT}$ of the cervical spine. Post-operative plain radiographs 1-2 days after surgery then at 3, 6 and 12 month to judge fusion.

\section{Surgical technique:}

All patients were operated upon under general anesthesia, in the supine position with the patient's head in mild extension on a horse shoe head rest with a rolled towel between the patient's shoulder blades. The shoulders were taped gently to the sides of the OR table to facilitate imaging down to the $\mathrm{C} 7-\mathrm{T} 1$ region. The elbows were padded to avoid compression.

A right-sided approach was performed via a transverse or longitudinal incision. The platysma was extensively undermined to provide tissue relaxation and prevent retraction-induced injury. Blunt dissection was used to dissect down to and expose the ventral aspects of the vertebral bodies. The prevertebral fascia and longus coli muscles were divided using electrocautery. Intraoperative fluoroscopy was used to confirm the operative levels. Lateral retraction blades were placed bilaterally under the medial edges of the longus coli musculature. Distraction posts were placed in the vertebral body above and the vertebral body below the interspace to be treated.

With the aid of the operating microscope, reaming of adjacent vertebral bodies, appropriate discectomy, removal of posterior longitudinal ligament (not routinely indicated but performed when the adequacy of the decompression is in question or 
when there was concern of an extruded disc fragment through the ligament) and drilling of the osteophyte (using high speed drill) or removal using $1 \mathrm{~mm}$ Kerrison rongeur were performed to decompress the spinal cord and nerve roots.

Based on the extent of the discectomy defect, an appropriate interbody fusion cage was placed. An extra step in Group (B) only, the cage was filled with synthetic bone granules. In case of double levels, we started surgery at the most compressive level and then sequentially moved to the next level and complete the process as well. This wass followed by proper hemostasis and closure in layers.

\section{Results}

42 patients were included in the study. The mean age was 46,18 of them were female and 24 were male. 25 patient had single level discs and 14 patients had two levels.

One year follow-up fusion rates achieved in:

- Group (A) 81.8\%.

- Group (B) 95\%.

\section{Alignment of cervical spine after surgery:}

Group (A)was exellant 90.9\%-Group (B) was exellant $95 \%$ making considerations for patient's age, sex, osteoporosis, and smoking habits in both group. Also radiographic findings (cervical X-ray) early post-operative and every 3 month till 24 month to asset fusion rate.

Lateral radiographs in flexion and extension showed no motion at operated levels in both group. One year after surgery, bone bridged the site of disc removal in 18 of 22 in Group (A) and 19 of 20 in Group (B) (significant difference ( $p 0.5)$ Fisher exact probability test statistic value is 0.823 .

Alignment of the cervical spine was excellent in 20 patient and 2 patient was good in Group (A) and 19 patient was exallent and one patient was good in Group (B). (Significant difference ( $p 0.5)$ Fisher exact probability test statistic value is 1 . Disc height is maintain in both group. Alignment of the cervical spine was judged to be excellent if normal cervical lordosis was retained, good if there was loss of lordosis and/or anterior angulation of less than $5 \sim$.

Fusion in single level comparing to double level, also age sex, smoker habit have no significant devefrance in both group.
There were no problems regarding surgical technique or dislodgment in both techniques. Only in one patient in Group A CSF leak developed and resolved. One patient in Group B developed a keloid at incision site.

Table (1): Clinical finding.

\begin{tabular}{lcccccc}
\hline \multirow{2}{*}{ Findings } & \multicolumn{2}{c}{$\begin{array}{c}\text { ACDFI }- \\
\text { bone granul }\end{array}$} & & \multicolumn{2}{c}{$\begin{array}{c}\text { ACDFI + } \\
\text { bone granul }\end{array}$} \\
\cline { 2 - 3 } \cline { 6 - 7 } & Number & $\%$ & Number & $\%$ \\
\hline Neck, shoulder pain & 17 & 77 & & 15 & 75 \\
Radicular pain & 20 & 90.9 & & 18 & 90 \\
Upper extremity weakness & 0 & 0 & & 1 & 5 \\
\hline
\end{tabular}

Table (2): Distribution of patients by level of operation.

\begin{tabular}{lcccc}
\hline \multirow{2}{*}{ Findings } & \multicolumn{2}{c}{ ACDFI - bone granul } & \multicolumn{2}{c}{ ACDFI + bone granul } \\
\cline { 2 - 5 } & Number & $\%$ & Number & $\%$ \\
\hline C3-4 & 1 & 4.2 & 1 & 5 \\
C4-5 & 3 & 14 & 2 & 10 \\
C5-6 & 9 & 40.9 & 9 & 45 \\
C6-7 & 9 & 40.9 & 8 & 40 \\
\hline Total & 22 & 100 & 20 & 100 \\
\hline
\end{tabular}

Table (3): Results of operation.

\begin{tabular}{lcccc}
\hline \multirow{2}{*}{ Findings } & \multicolumn{2}{c}{ ACDFI - bone granul } & \multicolumn{2}{c}{ ACDFI + bone granul } \\
\cline { 2 - 5 } & $\mathrm{N}$ & $\%$ & $\mathrm{~N}$ & $\%$ \\
\hline Excellent & 8 & 36.4 & 8 & 40 \\
Good & 9 & 40.9 & 8 & 40 \\
Fair & 4 & 18.2 & 3 & 15 \\
Poor & 1 & 4.5 & 1 & 5 \\
\hline
\end{tabular}

- Excellent: All pre-operative symptoms relieved, abnormal signs unchanged or improved.

- Good: Minimum persistence of pre-operative symptoms, abnormal signs un-changed or improved.

- Fair: Definite relief of some preoperative symptoms, others unchanged or slightly improved.

- Poor: Signs and symptoms unchanged.

Table (4): Results of fusion.

\begin{tabular}{|c|c|c|c|c|}
\hline \multirow{2}{*}{ Findings } & \multicolumn{2}{|c|}{ ACDFI - bone granul } & \multicolumn{2}{|c|}{ ACDFI + bone granul } \\
\hline & $\mathrm{N}$ & $9 / 0$ & $\mathrm{~N}$ & $\%$ \\
\hline Fusion & 18 & 81.8 & 19 & 95 \\
\hline
\end{tabular}

Table (5): Alignment of cervical spine after surgery.

\begin{tabular}{lcccccc}
\hline \multirow{2}{*}{ Alignment } & \multicolumn{2}{c}{ ACDFI - bone granul } & & \multicolumn{2}{c}{ ACDFI + bone granul } \\
\cline { 2 - 3 } \cline { 5 - 6 } \cline { 5 - 6 } Excellent & $\mathrm{N}$ & $\mathbf{O}$ & & & $\mathrm{N}$ & $\%$ \\
\hline Good & 20 & 90.9 & & 19 & 95 \\
\hline
\end{tabular}

- Differences were statistically significant $(p<0.5$, Fisher exact test statistic value is 1 ). 


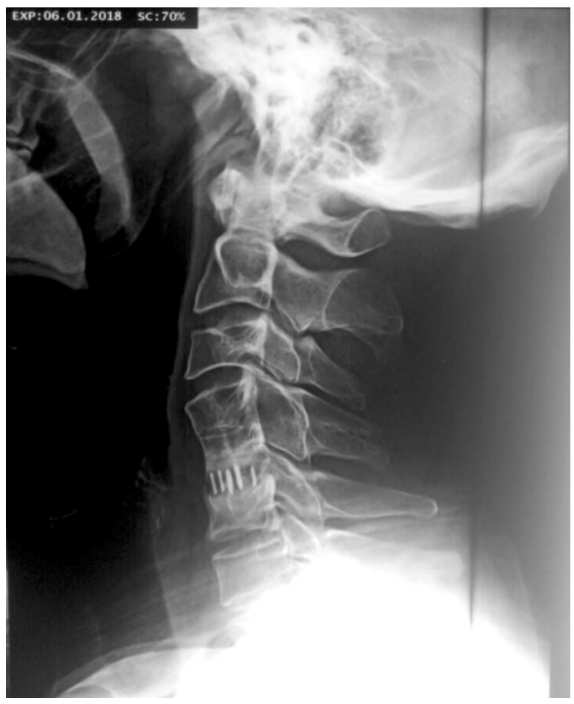

Fig. (1A): Early post-operative with bone granule.

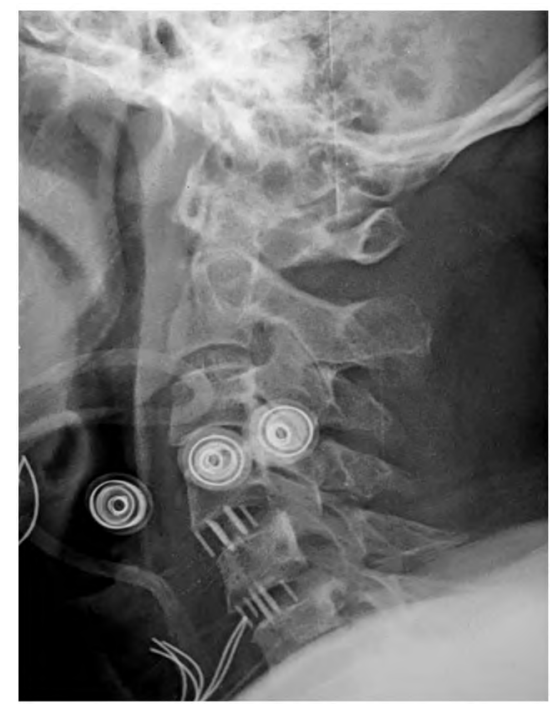

Fig. (2A): 1 st day of surgery.

\section{Discussion}

This study revealed a radiologic and clinical long-term result with an over average 1 year followup data after ACDFI surgery. The main stream of the published data about results after ACDFI with and without bone substitutes included fusion rates higher than $90 \%$ mostly without significant clinical relationship, therefore, the researchers suggested that the outcome of the stand-alone cage procedure was adequate.

After following patients from both groups for one year, Group (A) patients seemed to have inferior results in terms of fusion rate according to this study. Moreover, the fusion rate of $81.8 \%$ meant the non-fused index segments did not achieve bone fusion eventually although 12 months have passed.

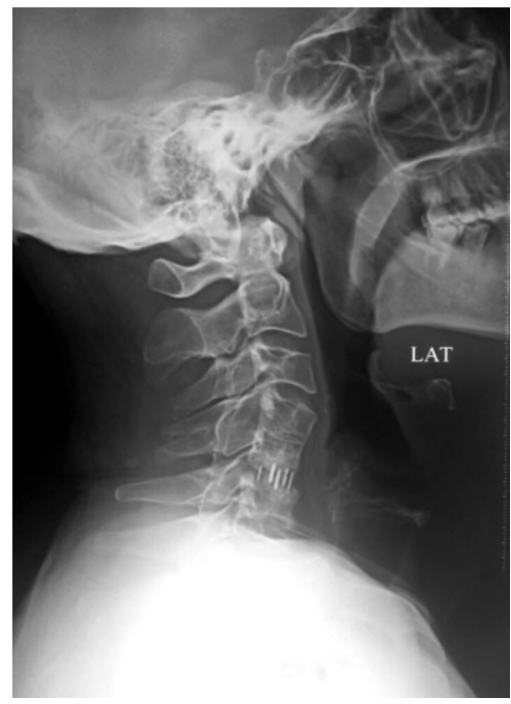

Fig. (1B): 12 months post-operative with bone granule.

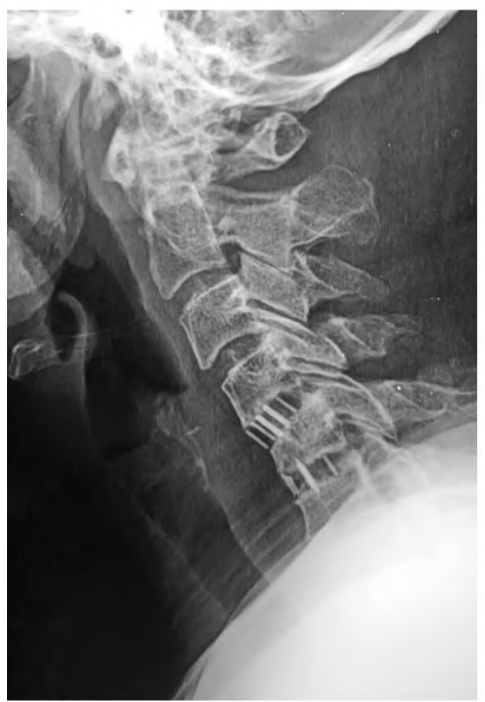

Fig. (2B): 12 months post-operative without bone granule.

The relationships between the demographic data and radiologic/clinical outcome had no statistical significance. Previous literature demonstrated that gender, age, level of surgery, cage height and BMD had no significance as outcome factors of the ACDFI surgery [1,2].

Previous researchers suggested that patients having ACDFI experienced pain relief according to the VAS score for two-year follow-up. However, this study demonstrated that the neck and arm VAS score at one year follow-up was comparable to published results. Clinical and radiologic outcome had no statistical relationship in this study, overall results of ACDFI without bone granules had shown to be less satisfactory with the course of time $[15,16]$. 
This unsatisfactory outcome by increased VAS score meant that patients were less satisfied in Group (A). Although we failed to find key factors that affecting the inferior outcomes, it seems that ACDFI without bone granules surgery did not have superiority to ACDFI with bone substitute technique $[15,16]$.

We recommend that treatment of patients with degenerative cervical spine disease, various factors (age, general condition, surgical level, bone quality) should be considered thoroughly for ideal care.

Limitations to our study included its the number of case limitations, the enrolled patients in this study were not randomized meaning possibility of biased data and the lack of comparing control group with ACDF without instrumentation. The operations were not performed by a single surgeon, and operative details like extent of endplate preparation or the make and model of the cervical cages used were not standardized.

Despite a twelve months follow-up, the key factors were not identified clearly for the unsatisfactory outcome of ACDFI with or without bone granules. Investigations about other factors like, meta-analysis of environmental aspects or patients' specific factors would be helpful for determining the accurate outcome evaluation of ACDFI surgery.

\section{Conclusion:}

Fusion rate is one of several factors that guide surgical decision making for cases requiring ACDFI. Fusion rate is significantly higher in Group (B) using cages filled with synthetic bone granules than in Group (A) with cages only. Age, sex, and smoking status have not given significantly different results between both groups studied.

\section{References}

1- BRENK E.C., DOSTAL M., SCHARF J., WEIB C., SCHMIEDER K. and BARTH M.: Influence of cervical bone mineral density on cage subsidence in patients following stand-alone anterior cervical discectomy and fusion. Eur. Spine J., 24: 2832-40, 2015.

2- BURKHARDT J.K., MANNION A.F., MARACHER S., KLEINSTUCK F.S., JESZENSZKY D. and PORCHET F.: The influence of cervical plate fixation with either autologous bone or cage insertion on radiographic and patient-rated outcomes after two-level anterior cervical discectomy and fusion. Eur. Spine J., 24: 113-9, 2015.

3- CABRAJA M., OEZDEMIR S., KOEPPEN D. and KROPPENSTEDT S.: Anterior cervical discectomy and fusion: Comparison of titanium and polyetheretherketone cages. B.M.C. Musculoskelet. Disord., 13: 172-4, 2012.
4- CANNADA L.K., SCHERPING S.C., YOO J.U., JONES P.K. and EMERY S.E.: Pseudoarthrosis of the cervical spine: A comparison of radiographic diagnostic measures. Spine (Phila Pa 1976), 28: 46-51, 2003.

5- FUJIBAYASHI S., NEO M. and NAKAMURA T.: Standalone interbody cage versus anterior cervical plate for treatment of cervical disc herniation: Sequential changes in cage subsidence. J. Clin. Neurosci., 15: 1017-22, 2008.

6- GRRCEK E., ARLET V., DELISLE J. and MARCHESI D.: Subsidence of stand-alone cervical cages in anterior interbody fusion: Warning. Eur. Spine J., 12: 513-6, 2003.

7- HADEN N., LATIMER M., SEELEY H.M. and LAING R.J.: Loss of inter-vertebral disc height after anterior cervical discectomy. Br. J. Neurosurg., 19: 469-74, 2005.

8- JOO Y.H., LEE J.W., RHEE J.J. and LEE H.K.: Comparison of fusion with cage alone and plate instrumentation in two-level cervical degenerative disease. J. Korean Neurosurg. Soc., 48: 342-6, 2010.

9- KAO T.H., WU C.H., CHOU T.C., CHEN W.H. and TSOU H.K.: Risk factors for subsidence in anterior cervical fusion with stand-alone polyetheretherketone (PEEK) cages: A review of 82 cases and 182 levels. Arch. Orthop. Trauma. Surg., 134: 1343-51, 2014.

10- KARIKARI O., JAIN D., OWENS T.R., GOTTFRIED O., HODGES T.R. and NIMJEE S.M.: Impact of subsidence on clinical outcomes and radiographic fusion rates in anterior cervical discectomy and fusion: A systematic review. J. Spinal Disord. Tech., 27: 1-10, 2014.

11- KAST E., DERAKHSHANI S., BOTHMANN M. and OBERLE J.: Subsidence after anterior cervical inter-body fusion. A randomized prospective clinical trial. Neurosurg. Rev., 32: 207-4, 2009.

12- LEE C.H., HYUN S.J., KIM M.J., YEOM J.S. and KIM W.H.: Comparative analysis of 3 different construct systems for single-level anterior cervical discectomy and fusion: Stand-alone cage, iliac graft plus plate augmentation, and cage plus plating. J. Spinal Disord. Tech., 26: 112-8, 2013.

13- LEE C.H., KIM K.J., HYUN J.S., YEOM J.S., JAHNG T.A. and KIM H.J.: Subsidence as of 12 months after single-level anterior cervical inter-body fusion. Is it related to clinical outcomes? Acta. Neurochir. (Wien), 157: 10638, 2017.

14- MAROTTA N., LANDI A., TARANTINO R., MANCARELLA C., RUGGERI A. and DELFINI R.: Five-year outcome of stand-alone fusion using carbon cages in cervical disc arthrosis. Eur. Spine J., 20 (Suppl 1): S8S12, 2011.

15- YUE W.H., BRODNER W. and HIGHLAND T.R.: Longterm results after anterior cervical discectomy and fusion with allograft and plating: A 5- to 11-yearradiologic and clinical follow-up study. Spine (Phila Pa 1976), 30: 213844, 2005.

16- ZOEGA B., KARRHOLM J. and LIND B.: Outcome scores in degenerative cervical disc surgery. Eur. Spine J., 9: 137-43, 2000. 


\section{دراسة مقارنة لجراحات التثبيت العنقى بإستخدام الآقفاص الكريونية

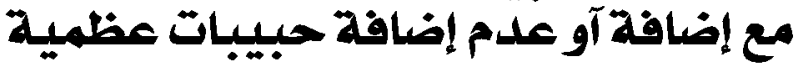

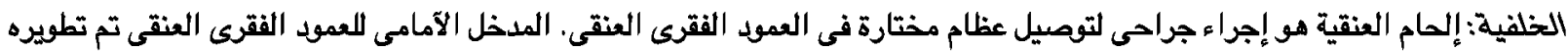

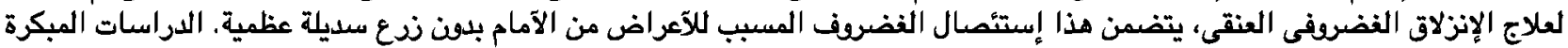

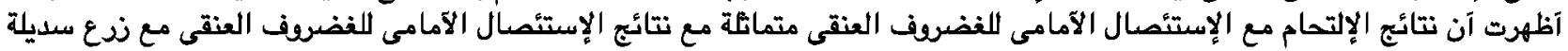
عظمية.

جراحات إستئصال الإنزلاق الفضروفي العنقى الآمامية مع ندع سليلة عظمية والتثبيت بالوسانط الجراحية هو آسلوب جراحى يتضمن

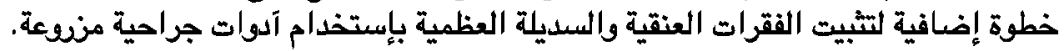

الآ قفاص تم تطويرها كى تستعمل مع العظام الذاتية للمريض آو العظام المناعية لدعم الإستقرار وتشجيع الإلتحام فى العمد الفقرى.

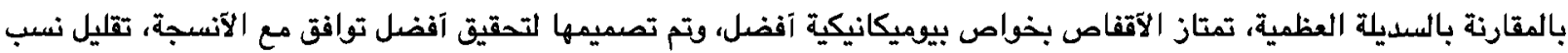

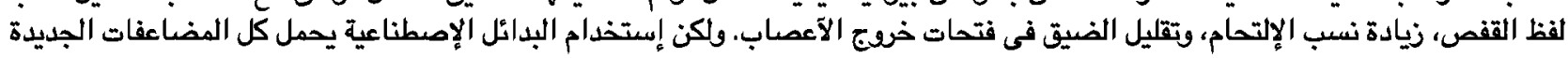
الخاصة بها.

الهدف: هذه الدراسة المستقبلية تهدف لمقارنة نتائج الإستئصال الآمامى للغضروف العنقى مع الإلحام والتثبيت الجراحى بإستخدام

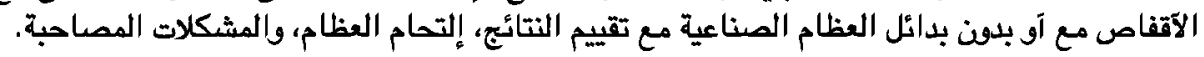

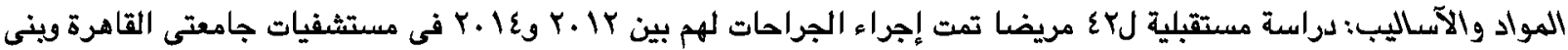

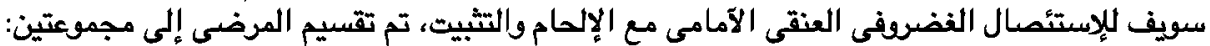

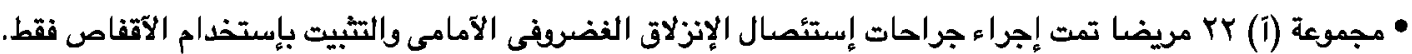
• مجموعة (ب) •Y مريضا تمت إجراء جراحات إستئصعال الإنزلاق الفضروفى الآمامى والتبيت بإستخدام الآقفاص وبدائل العظم الإصطناعية.

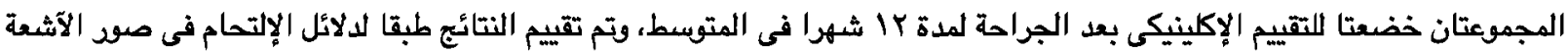
وإختبار فيشر لتاكيد الإحتمالات لمقارنة الإلتحام في المعلى المجموعتين.

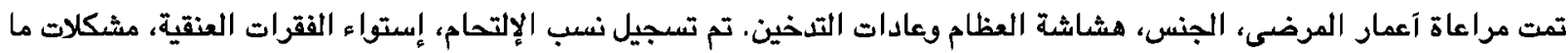

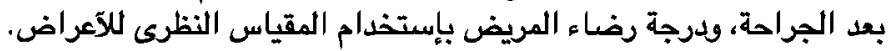

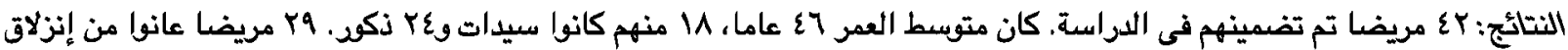
غضروفى على مستوى واحد وبا عاني عانوا من مستويين.

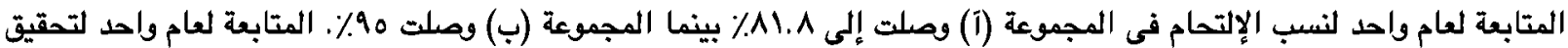
الإستواء اللفقرات العنقية كانت 9 . 9\% من المرضي في في المجموعة (آ) وفى المجموعة (ب) كانت

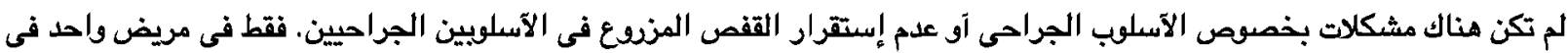

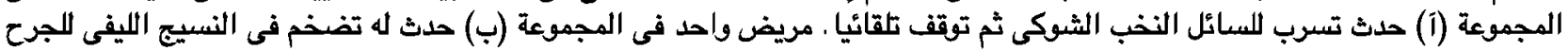
الجراحى.

الخلاصدة: نسبة الإلتحام واحدة من عدد من العوامل التى تلدم قرار الجراحة للحالات المرضية التى تحتاج للإستصلاح الآمامى للإنزلاق

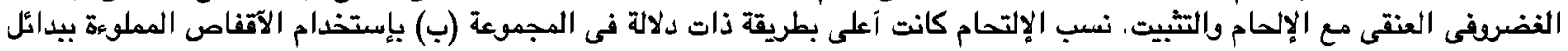
العظام الصناعية عن المجموعة (آ) بالآقفاص فقط. العمر، الجنس، وعادات التدخين لم تعطى دلالات مؤثرة لتغيير النتائج بين المجموعتين. 